\title{
Fetal Descent
}

National Cancer Institute

\section{Source}

National Cancer Institute. Fetal Descent. NCI Thesaurus. Code C92783.

The movement of the fetus led by the presenting part into the maternal pelvic cavity during active labor. 